\title{
International Students' Experiences of Public Administration Activity in the Host Country: Revealing Patterns of Administrative Culture
}

\author{
Ramunė Miežanskienè \\ Kaunas University of Technology \\ A. Mickevičiaus 37, LT-44244 Kaunas, Lithuania \\ Aušra Tartilaitė-Paulauskienė \\ Kaunas University of Technology \\ A. Mickevičiaus 37, LT-44244 Kaunas, Lithuania \\ cross $^{r e f}$ http://dx.doi.org/10.5755/j01.ppaa.19.1.24870
}

\begin{abstract}
The conducted research is aimed to identify those patterns in which administrative culture is distinguished while addressing the immigrants' experiences related to administrative behaviour of state institutions and public servants in the host country. The conducted research particularly focuses on international students' experiences in Lithuania. Therefore the analysis draws insights using a qualitative survey data where the international students' of Kaunas municipality in Lithuania reveal their experiences, related to the behaviour of public service officials. For so, the conducted research explores students' socio-demographic characteristics in their relation to experiences while carrying administrative activities. Consequently, the data is being used to support and illustrate the given arguments in how administrative culture distinguishes itself in the migrationrelated performance field. The main findings from the analysed data support arguments that in those cases when migrant's situation is being addressed, the administrative culture of the host country is admitted to have its own distinctive features. The case study of Kaunas municipality of Lithuania reveals that the immigrant-related administrative culture distinguishes oneself while facilitating such features as (I) restrictiveness in language usage policy which in turn creates obstacles for immigrants to obtain optimal access to information and (II) features of not sufficiently responsive administrative behaviour. Overall, the originality and the value the research gives additional input by revealing in what way administrative culture distinguishes oneself while addressing the immigrants case and at the same time, indicates the scope for public leadership in migrant related public administration activity.
\end{abstract}

Keywords: administrative culture, immigration, international students.

Raktažodžiai: administracinè kultūra, imigracija, tarptautiniai studentai.

\section{Introduction}

As research on administrative culture gains its prominence in the field of public administration (Jamil, Askvik, Hossain, Jamil, \& Askvik, 2013), it is also seen that the scope of this scientific discourse is greatly distinguished with a diversity of conceptualizations in the related, but more focused spheres, such as administrative behaviour or administrative politics, and governance reforms. Considering the variety of research that could be combined under the umbrella of administrative culture, the new variables, such as the impact of administrative culture towards diversified groups and the experiences of administrative culture by particular groups of society, open up a niche to create valuable input in this field of scientific discourse. While seeking to address the latter, this paper suggests making a deeper enquiry into the specifics and address the immigrants' experiences of 
administrative culture in a host country. With respect to that, the aim of the research is to explore the experiences of immigrants when they encounter the implementation of public administration in a host country, and inevitably have to face its administrative policy. Moreover, to address the impact that administrative culture has on its clients while diversifying immigrants' position, as opposed to that of native residents. This further leads to the search of those features of administrative culture that is brought into relationship with migrants in a host country. Therefore, this research investigates and explores central patterns of administrative behaviour, as well as the dimensions of administrative policy directed towards foreigners. Considering the latter, this paper addresses the administrative culture as a multidimensional phenomenon though not only focusing on the dimension of administrative responsiveness but also trying to mark out the portrait of administrative politics from the perspective of migrants' situations. Subsequently, in this enquiry, we hypothesise that administrative culture in the form of administrative behaviour and administrative policy would open up and display it's distinctiveness towards migrants as clients. In addition to that, we hypothesise that there are certain sociodemographic characteristics which make immigrants (to be more precise regards the following group of interest- international students) vulnerable in the context of exposure to administrative culture in the host country. We agree with the notion that the style of administrative culture influences the role of government and its relationship with citizens (Ortiz-rodríguez and Navarro-Galera, 2015). However, we suggest to specify and deepen the knowledge in this field while looking towards the relationship with citizens/immigrants, which also expresses the patterns of administrative culture itself.

\section{Literature review}

As previously mentioned, the research field of administrative culture is distinguished by its complexity and diversity. While addressing the concept of administrative culture, it is generally approached as a set of values and norms in public organizations, though it may also be considered as part of a broader political culture (Jamil, 1994; Henderson, 2004; Jamil et al., 2015). Scholars tend to lean on already distinguished types of administrative cultures and use them as one of the key explanators further on (Kickert, 1997). In addition, cultural aspects in relation to public administration also became a separate interest for research, framing it as an important element in the process of administrative activity (Schröter, 2007; Schedler and Proeller, 2007; Lam, MacGregor; 2018, RuizLozano, 2019). According to R. D. Sharma (2002), all behaviours exhibit cultural traits or specific, distinguishable elemental properties. Therefore, they are administrative behaviours or actions. Administrative culture varies, being an object of research on a state level (Caiden 1970; Dwivedi and Gow, 1999; Jamil, 2007; Arellano-Gault, 2016; Marcheva 2016), as well as on a regional level to institutions. Further on Ishtiaq Jamil, Steinar Askvik and Farhad Hossain (2013) indicate several trends of research related to administrative culture such as concentrating on central bureaucracy, addressing the activity of top civil servants, and then distinguish studies with a narrower focus on deviant behaviour, corrupt practices, and the irregular, unpredictable behaviour of bureaucrats (Jamil et al., 2013). If to address administrative culture as a multidimensional phenomenon, researchers mark out dimensions such as (I) political responsiveness, or relationships between politicians and administrators; (II) social responsiveness, or relationships between society and administrators; (III) cohesion, or sources of internal authority and control (Jamil \& Dangal, 2009). At a macro level, administrative cultures are portrayed according to their patterns of activity associating with geographical regions as follows: Anglo-Saxon, Central European, Germanic, Nordic, and Southern European administrative culture (Kickert, 1997; Ortiz-rodríguez \& Navarro-galera, 2015). While referring to the scientific input in the topic and the work focus of administrative culture, scholars, generally, concentrate on values, norms, and attitudes held by the members of the civil service apparatus and its relation to the external subjects (Jamil et al., 2013), though there are not many elaborate studies on how administrative behaviour is experienced and perceived or experienced by particular groups of society. Following the levels of practical implication of the dimensions of administrative culture as administrative behaviour, there are reasonable grounds for pursuing to 
identify the connection between administrative culture and the patterns of experiences associated with specific groups of society as an outcome. Especially addressing and elaborating this topic related to socially distinctive groups as migrants.

\section{Methods and materials}

The analysis of migrants' experiences related to the work of governmental institutions in the host country will draw insights from international students' experiences while encountering with administrative behaviour of the countries' system of public administration. To be more precise and to state that within the framework of research - encountering the behaviour of public officials of the host country, which constitutes a feature of host countries administration.

The same as other groups of immigrants, international students share the common feature of being "new" in the host society. Though they also share some of the differences in comparison to what had been the main reason for coming to the host country. Being a refugee, labour migrants or coming on the legal basis of family reunion might distinguish each of the group and that should also be taken into consideration. For this reason, this research paper specifically addresses experiences of one of the particular groups of migrants - education-driven migrants.

While addressing the culture aspect, the research will also refer to the general policy of the host country regarding the aspect of language use policy. The analysis approaches the data set of quantitative set of surveys conducted in five universities and representing the case of a particular Kaunas municipality in Lithuania. Surveys in universities were carried out between 2017 and 2018 with the aim of addressing the experiences of international students, related to legal and administrative behaviour of institutions in the host country. The following research in this paper analyses the case of the second largest of the municipalities of Lithuania and sets its target population as residents in Lithuania in a study year of 2016/2017. In this academic year, the universities welcomed almost one-third of international student residents, constituting a target population of 2170 , out of a given total population of 6595 of international students who were studying in Lithuania. The following analysis is based on descriptive data and a hypothesis on relations presented with $95 \%$ of the confidence level and $5 \%$ margin of error. In this particular case, the analysis has addressed the answers of 288 respondents out of five universities in the municipality of Kaunas. Firstly, a particular design of the questionnaire was set to explore the scope of challenges related to administrative procedures. Students were asked to share whether they had experienced challenges related to administrative behaviour, and if they had, how frequently they had experienced such challenges, as well as what kind of patterns were mostly observed. As follows, respondents were asked to identify 1) the frequency of challenges related to the implementation of their rights while having a contact with Lithuania's governmental institutions; 2) the field and frequency of challenges related to legal regulations in Lithuania: carrying out administrative procedures; 3 ) the type of challenges related to language use; and 4) the type of challenges related to administrative procedures (referring to governmental institutions). The latter two questions were given with a possibility for respondents to choose from a list with an open space left for other possibilities to submit an individual answer too. The design of the pre-given choices of answers was included as a result of prior research as observations, explorative in-depth interviews, and therefore identified as possible instances of experiences in the scope of challenges, related to administrative procedures. In order to indicate the type of challenges related to language use, the respondents were given to verify the following statements: a) information related to legal regulation is provided in Lithuanian; b) officials or state officers do not use or have poor skills of a language other than Lithuanian; c) administrative forms are not adapted to foreign residents (there is no translation or manual how to fill them in); d) other. While pursuing the identification of the type of challenges related to administrative procedures, the subsequent choices were given as a) bureaucracy, b) unwillingness of officials to provide information in detail; c) shortage of clear and precise information; d) other.

Furthermore, for the more elaboration of the phenomenon of international students' encountering the host country's administrative culture, the socio-demographic characteristics of the 
respondent's were taken into consideration as well. The Pearson chi-square statistic was used to find out if the specific (socio-demographic) characteristics of respondents have any difference regarding their experiences of challenges related to administrative procedures in the host country. The main aim of this was to test if there was a relation between the following features as a) age; b) gender; c) permanent place of residence; d) the type (format) of studies respondents were conducting; e) duration of residence in the host country and the indication of experiencing challenges while carrying out administrative activities in the host country. While the null hypothesis stated that there was no relation between respondents' characteristics, the alternative hypothesis had presumed that there was one.

\section{Uncovering the scope and patterns of challenges related to administrative procedures}

Administrative procedures encompass the implementation of laws and regulations which are a subject of the application in any case whether they are being dedicated to a native resident or to a new resident of a host country. While analyzing the case of Lithuania and the patterns of its public service activity, we have to refer to the primary principles which are set in the Constitution of the Republic of Lithuania. The grounding provisions of the document state, that all governmental institutions serve to the people and not only native residents. Looking from a closer perspective, serving to people would not be possible without public administration and the full scope of its" activities. According to the Law on Public Administration (referring to article no 2), this encompasses the activity of public administration bodies for the laws and regulations to be implemented: administrative decisions, the control of implementation of laws and administrative decisions, the activity of provision of administrative services, public service administration and internal administration (Law on Public Administration, 2019). While referring to how it's being done, it leads to addressing the quality of actual public services in Lithuania. In this case, researchers identify that it is not conforming to the native citizens' expectations. There could be also outlined that the value of services provided to citizens is associated with the technological (e-government) decisions, but as it is mentioned in previous research, this accessibility does not compensate for certain gaps related to unacceptable consulting, improper behaviour, and additional restrictions on the reception of service (Pivoras, Civinskas and Kaselis, 2017). We acknowledge that trying to identify the features of Lithuania's public administration activity could possibly vary because of immigrants experiences that might have a different frequency and intensity of contact with public service activity in the host country. If institutions are being addressed not as often or obtain a narrower range of institutions that clients have to go to it might also produce a different picture compared to the experiences of public administration of native residents. In order to see to what extent the activity of governmental institutions and procedures are considered to be part of challenges in immigrants' life (in this case - international students'), there comes a necessity to investigate how often these procedures are being encountered and market in their consciousness as „challenging“. In addition to that, identify what are the patterns of those experiences. Following this, respondents of the poll were asked to identify how often do they experience challenges related to the implementation of their rights while encountering the host countries governmental institutions. The data revealed that nearly half of respondents $45,5 \%$ had experienced challenges at least once in a year. There should be also mentioned that $15,6 \%$ of respondents indicated to encounter these challenges at least once a month which reveals a quite frequent and not resultative encounter with governmental institutions. In order to narrow the focus of research enquiry the question was asked about the challenges regards administrative procedures. The latter revealed a higher proportion of challenge-based instances - at least six of ten students (64.2\%) admitted of facing challenges while carrying out administrative procedures. Around the same percentage $(16.6 \%)$ as in the previously addressed question (which was 15,6\%) of the respondents stated to be facing them quite often or even constantly. In comparison to other spheres which international students were encountering with as a civil legal relationship (for example contracting) or related to employment activities in the host country, the frequency of facing challenges in the field of 
administrative procedures appear to be the highest and most prominent and evident to see by its numbers (table 1).

Table 1. Frequency of facing challenges in the field of carrying out administrative procedures, employmentrelated activities and contracting

\begin{tabular}{|l|c|c|c|}
\hline & $\begin{array}{c}\text { Carrying out administrative } \\
\text { procedures }\end{array}$ & $\begin{array}{c}\text { Carrying out } \\
\text { employment activities }\end{array}$ & Contracting \\
\hline Never & $34.4 \%$ & $61.1 \%$ & $52.4 \%$ \\
\hline Once or twice & $47.6 \%$ & $18.4 \%$ & $28.5 \%$ \\
\hline Quite often & $9.7 \%$ & $10.4 \%$ & $12.8 \%$ \\
\hline Constantly & $6.9 \%$ & $6.3 \%$ & $3.5 \%$ \\
\hline N/A & $1.4 \%$ & $3.8 \%$ & $2.8 \%$ \\
\hline
\end{tabular}

Note. Built on data (survey data „Legal Environment in Lithuania: International Students' Experiences and Expectations", 2018)

\section{The role of international students' characteristics and experiencing challenges while carrying out administrative procedures}

In further elaboration of the topic, we have addressed the field of respondent's experiences and their socio-demographic characteristics, in order to investigate if there are any certain features of characteristics where immigrants (international students) should be considered to be more vulnerable or in need of assistance in the context of exposure to administrative procedures in the host country. This research enquiry led us to test whether challenges while carrying out administrative procedures are concerning particular respondents' characteristics. Therefore subsequent hypotheses from A to E (table 2) were tested to indicate if there are features of respondents characteristics which might be associated with the phenomenon of experiencing administrative challenges. We have tested the null (Ho) hypothesis, which stated that there was no relation between respondents characteristics the alternative hypothesis ( $\mathrm{H} 1)$, which presumed that there was one as follows:

a) Hypothesis A: Ho - there is no relation between the respondent's age and experiencing challenges while carrying out administrative procedures in the host country;

b) Hypothesis B: Ho - there is no relation between the respondent's gender and experiencing challenges while carrying out administrative procedures in the host country;

c) Hypothesis C: Ho - there is no relation between the respondent's permanent place of residence and experiencing challenges while carrying out administrative procedures in the host country;

d) Hypothesis D: Ho - there is no relation between respondent's type of studies and experiencing challenges while carrying out administrative procedures in the host country;

e) Hypothesis E: Ho - there is no relation between respondent's duration of residence in the host country and experiencing challenges while carrying out administrative procedures in the host country.

As it was mentioned in the previous section (Uncovering the scope and patterns of challenges related to administrative procedures) we can identify a large proportion of students who have proclaimed to face challenges while conducting administrative procedures in Kaunas municipality of Lithuania. While addressing a set of the socio-demographic characteristics of students, we have noticed some characteristics to display a relation to the phenomenon of experiencing challenges in the field of public administration. As the $\mathrm{p}$ in the test of before mentioned hypotheses „B“, „D“ and „E“ comes with the value of significantly less than 0.05 , it is eligible to reject the null hypotheses and accept the alternative ones. In this case, we can confirm that there is a relation with (each),,gender“, „type of studies“ as well as the „duration of residence in the host country" and the occurrence of challenge-based experiences while carrying out administrative procedures in the host country. In the case of gender characteristic (hypothesis „B“), this relation reveals itself as a moderate one. Though, 
considering „type of studies“ and „duration of residence in the host country“ (hypothesis „D“ and „E") it comes with a strong relation, and we can state that it is important to consider ,type of studies" and ,duration of residence in the host country“ as key predictors for a group that needs an adequate approach providing further attention. This also indicates a field for administrative leadership to step in to as well.

Table 2. The relation between the respondent's characteristics and experiencing challenges while carrying out administrative procedures in the host country

\begin{tabular}{|c|c|c|c|c|c|}
\hline Characteristics & Hypothesis A & Hypothesis B & Hypothesis C & Hypothesis D & Hypothesis E \\
\cline { 2 - 6 } & Age & Gender & $\begin{array}{c}\text { Permanent } \\
\text { place of } \\
\text { residence }\end{array}$ & $\begin{array}{c}\text { Type of studies } \\
\text { (exchange or full- } \\
\text { time degree studies) }\end{array}$ & $\begin{array}{c}\text { Duration of } \\
\text { residence in the } \\
\text { host country }\end{array}$ \\
\hline $\begin{array}{c}\text { Pearson Chi-Square } \\
\text { value }\end{array}$ & 0.24 & 0.03 & 0.085 & 0.01 & 0.02 \\
\hline Cramer's V & 0.09 & 0.13 & 0.10 & 0.15 & 0.20 \\
\hline
\end{tabular}

Note. Built on data (survey data „,Legal Environment in Lithuania: International Students' Experiences and Expectations", 2018)

Following the subsequent data, we are able to notice, that within the variable of gender, male tend to indicate an experience of administrative challenges more often $(68.4 \%)$ than female $(54.3 \%)$ and full-time students identify experiencing challenges more often $(68.1 \%)$ than exchange students $(48.9 \%)$. There should also be pointed out that students' responses reveal that they are facing beforementioned challenges in the 3rd-4th years $(86.1 \%)$ of residing in the host country. These are the last year for international students to finish their bachelor degree studies in Lithuania, and it also appears to be a time of uncertainty, where some of the related problems are solved by addressing public administration institutions and officials.

\section{International students' experiences while encountering public administration activity of host country}

While elaborating the aspect of international students' particular experiences encountering public administration activity in Kaunas municipality in Lithuania, the research presents some insights as well. We have found, that while challenges, related to administrative procedures might obtain a variety of forms, the subsequent data shows that in the given case it has it's the certain leading pattern as well (table 3). Almost one-fifth of respondents have identified "bureaucracy" $(19,8 \%)$ at present. That actually does correspond to the general trend in the host country. Though there is another issue which is raising more of concern and brings forward the presumption about administrative hostility. To be precise, the data of the poll identifies that quite a large part of international students assume to be treated with hostility. This presumption is related to the fact that every third of respondent points out the "unwillingness of officials to provide information in detail". We must also notice that this particular set of questions is more sensitive which is revealed by the fact that $11,1 \%$ of respondents did not answer this particular question. That indicates the need for a more elaborate and qualitative type of methodological approach in further research approach.

Subsequently, the core and the most common challenge is noted as "shortage of clear and precise information" which is encountered by every second international student. Finally, the plain disclosure of the situation opens up by providing a portrait of the coverage of before mentioned three patterns of administrative challenges. The majority of international students (85\%) stated to find one or the other kind of challenge regards the administrative procedures of the host country (table 3 ). Each and every pattern signals about some of the aspects of the administrative culture of the host country. While the features we address like the pattern of "bureaucracy" refers to the flaws of the system", the different angle opens up if we address the "Unwillingness to provide information in 
detail" which points to certain experiences as attitude based administrative behaviour. Finally "shortage of clear and precise information" represents both of them. In resume, what concerns administrative procedures in the host country, the position that international students are left with looks much like a "blind alley".

Table 3. Frequency of identifying bureaucracy, the unwillingness of officials to provide information in detail and shortage of clear and precise information

\begin{tabular}{|c|c|c|c|}
\hline & $\begin{array}{c}\text { Identified } \\
\text { as challenge }\end{array}$ & $\begin{array}{l}\text { Not identified } \\
\text { as a challenge }\end{array}$ & NA/ other \\
\hline Bureaucracy & $19.8 \%$ & $69.1 \%$ & $11.1 \%$ \\
\hline The unwillingness of officials to provide information in detail & $32.6 \%$ & $56.3 \%$ & $11.1 \%$ \\
\hline Shortage of clear and precise information & $55.9 \%$ & $33.0 \%$ & $11.1 \%$ \\
\hline $\begin{array}{l}\text { Under the coverage of: "Bureaucracy", "Unwillingness of } \\
\text { officials to provide information in detail", "Shortage of clear } \\
\text { and precise information". }\end{array}$ & $85.1 \%$ & $3.8 \%$ & $11.1 \%$ \\
\hline
\end{tabular}

Note. Built on data (survey data „Legal Environment in Lithuania: International Students' Experiences and Expectations", 2018)

The before mentioned descriptive data brings into consideration the fact that at least eight of ten international students in the given case of a particular municipality in Lithuania have encountered challenges related to the activity of administrative institutions. Furthermore, considering the magnitude of respondents that were identifying experiences within the framework of a „challenge“, it brings forward the signals for the actual need for a support system. It also urges to proceed in making a more detailed investigation of this phenomenon itself.

\section{Considering the host country's official language use policy}

The aspect of language use is considered to be one of the key features that distinguish immigrants form a local society of the host country, and also stated as one, that obtains most of the power in the process of integration. Following the data of the survey in regards this particular aspect of language, we find that international students depict it also as one of the key elements which come in front of consideration when they encounter administrative procedures (table 4).

Table 4. Challenges related to language use

\begin{tabular}{|c|c|c|c|}
\hline & $\begin{array}{l}\text { Identified as } \\
\text { challenge }\end{array}$ & $\begin{array}{l}\text { Not identified } \\
\text { as a challenge }\end{array}$ & NA/other \\
\hline $\begin{array}{l}\text { Information related to legal regulations is provided in Lithuanian } \\
\text { language }\end{array}$ & $53.5 \%$ & $42.4 \%$ & $4.2 \%$ \\
\hline $\begin{array}{l}\text { Officials or state officers do not use or have poor skills of another } \\
\text { language than Lithuanian }\end{array}$ & $60.4 \%$ & $35.4 \%$ & $4.2 \%$ \\
\hline $\begin{array}{l}\text { Administrative forms are not adapted to foreign residents (there } \\
\text { is no translation or manual on how to fill them) }\end{array}$ & $37.5 \%$ & $58.3 \%$ & $4.2 \%$ \\
\hline $\begin{array}{l}\text { Under the coverage of: "Information related to legal regulations is } \\
\text { provided in Lithuanian language“, „Officials or state officers do } \\
\text { not use or have poor skills of other languages than Lithuanian“, } \\
\text { „Administrative forms are not adapted to foreign residents“. }\end{array}$ & $92.4 \%$ & $3.5 \%$ & $4.2 \%$ \\
\hline
\end{tabular}

Note. Built on data (survey data „Legal Environment in Lithuania: International Students' Experiences and Expectations", 2018)

While addressing the aspect of language use, respondents were asked to select and/or write in challenges related to it. The question obtained a range of three already pre-given answers, including the possibility to add respondents' opinion of his own. In the given case, even the lowest percentage of respondents' answers (37.5\%) introduces language use as a field of challenge-based experiences. 
Even more, when it comes to the complete coverage of all three choices, it is uncovering that the absolute majority of international students in Kaunas municipality have faced one of three challenges (Table 4) related to language use while encountering administrative procedures. The other aspect that has to be taken into consideration is that the emphasis should be put not only to the patterns of activity of institutions (provisions of information in the native language $(53.5 \%)$ or other language adoption to the procedures $(37.5 \%)$ but the aspect of competences of officials $(60.4 \%)$ (Table 4$)$.

Looking at closer range to the scope and ways of language use in administrative procedures in Lithuania, we find that it mainly depends on the language policy decisions and their prescriptions by legal regulations. Administrative procedures encompass the implementation of laws and regulations, which are a subject of the application in any case, whether they are being ordered to a native resident or the immigrant. While investigating from a closer range, the provisions of language usage, we find that the obligation to use the official language is established in the Law on the State Language of the Republic of Lithuania. The same, but in a different Law on Public Administration of Lithuania (in article no. 32) it is explicitly stated that the official language of administrative procedure must be "Lithuanian". In the case when a person is not able to communicate in official (Lithuanian language) the information must be translated to him although the duty to bring a translator to this procedure lies on the shoulders of the client unless the institution takes action to use its own resources for that. For this reason, there is some space left for public leadership in providing a translator/qualified official in all necessary cases. This free choice option implicates that there is a way of doing things differently. Although this freedom is up to some limits: the application procedure which involves written language comes with more of constrains. Article no 13.1 of the „Rules on the handling of applications and complaints on the treatment of persons in the public administration" is stating that "when submitting an application and a written complaint, the application and the complaint must be written in the official language or have a translation into the official language, where the authenticity would be certified in accordance with the procedure established by the Law on the Notary of the Republic of Lithuania. Although this requirement does not apply if the head of the institution has also determined other languages in which applications may be accepted or when a foreign authority or an international organization addresses the authority in writing in accordance with international law (Rules on the handling of applications and complaints on the treatment of persons in the public administration). Addressing previously mentioned, we find that administrative procedures are structured by constrains which are provided by the state itself and its formal policy.

In summarizing the legal provisions on official administrative language use and international students' experiences, there could be stated that administrative culture regards the immigrants obtain certain features of lack in responsiveness in their performance.

\section{Concluding remarks}

The conducted research was targeting to identify those patterns in which the administrative culture of the host country distinguishes while addressing the immigrant situation. As social responsiveness or relationships between society and administrators constitute a part of the administrative culture (Jamil \& Dangal, 2009) therefore the particular group of the society as immigrants (international students) are at the set of this interaction as well. The results of the research identify that international students' experiences could be reasonably determined to be at a margin of being different from the mainstream of native residents' experiences. The analysis of the case study in Kaunas municipality in Lithuania supports arguments, that the vast majority of international students are facing challenges while encountering administrative procedures in the welcoming municipality. As the intensiveness of experiencing challenges comes concerning the duration of the residence and the type of studies (exchange or full-degree), this presupposes the need for dedicated attention considering the time range of international students being in a host country. Whereas closer to graduation, students are involved in the decision-making process alongside the need for timely, accurate information which most likely evolves the need for interaction with local authorities and institutions. The following challenges that international students are facing comes in the form of a) 
beaurocracy; b) the unwillingness of officials to provide information in detail and c) shortage of clear and precise information. The latter and the official language usage policy tend to create obstacles for international students to obtain optimal access to necessary information due to public service behaviour. Therefore, immigrant-related administrative culture might be experienced by immigrants as facilitating such features: a) providing not sufficiently responsive administrative public service behaviour towards immigrants (international students); b) keeping restrictiveness in language usage policy. In a given case of obtaining restrictive official language policy and a vacuum of public leadership as well, it might lead to prevention from using a right to efficient public service activity in the host country.

The investigation of the international students' experiences of public administration activity in the host country also revealed it to be a sensitive topic to a certain group of respondents. In respect to that, further scientific researches could also benefit from a qualitative type of methodological approach.

\section{References}

1. Arellano-Gault, D. (2013). The Dilemma for the New Administrative Culture in Mexican Public Administration: Esprit de Corps or Individualist Bureaucracy? International Journal of Public Administration, 36(13), 940-952. https://doi.org/10.1080/01900692.2013.773029

2. Caiden, G. (1970). Israel's administrative culture. Berkeley: Institute of Governmental Studies, University of California.

3. Dwivedi, O. P. and Gow, J. I. (1999). From bureaucracy to public management: The administrative culture of the government of Canada. Peterborough, Canada: Broadview Press.

4. Government of the Republic of Lithuania. (2007). Rules on the handling of applications and complaints on the treatment of persons in the public administration. (2007 August 22 No. 875) [accessed 2019-12-11]. Retrieved from https://eseimas.lrs.lt/portal/legalAct/lt/TAD/TAIS.303479/asr

5. Jamil, I. (1994). Administrative culture: A mode of understanding public administration across cultures. In C. Coyle (Ed.) Research in Urban Policy ( pp. 275-294). Greenwich: JAI Press.

6. Jamil, I. (2007). Administrative culture in Bangladesh: Tensions between traditions and modernity. Dhaka: A.H. Development Publishing House.

7. Jamil, I., Askvik, S. and Hossain, F. (2015). Administrative Culture in Developing and Transitional Countries. London: Routledge, https://doi.org/10.4324/9781315746104

8. Jamil, I., \& Dangal, R. (2009). The state of bureaucratic representativeness and administrative culture in Nepal. Contemporary South Asia, 17(2), 193-211. https://doi.org/10.1080/09584930802346497

9. Jamil, I., Askvik, S., \& Hossain, F. (2013). Understanding Administrative Culture: Some Theoretical and Methodological Remarks. International Journal of Public Administration, 36(13), 900-909. https://doi.org/10.1080/01900692.2013.837728

10. Kickert, W. J. M. (1997). Public Governance in the Netherlands: An Alternative to AngloAmerican "Managerialism." Public Administration, 75(4), 731-752. https://doi.org/10.1111/1467-9299.00084

11. Lam, N. and MacGregor, J. (2018). Influence of ethnic values on public sector performance management. Asian Education and Development Studies, 7(2), 234-250. https://doi.org/10.1108/AEDS-06-2017-0056

12. Marcheva, D. (2013). Administrative Culture in Bulgaria: Sources, Foundations, and Transitions. International Journal of Public Administration, 36(13), 963-971. https://doi.org/10.1080/01900692.2013.773027 
13. Ortiz-Rodríguez, D., Navarro-Galera, A., \& Alcaraz-Quiles, F. J. (2015). The Influence of Administrative Culture on Sustainability Transparency in European Local Governments. Administration \& Society, 50(4), 555-594. https://doi.org/10.1177/0095399715616838

14. Ruiz-Lozano, M., Navarro-Galera, A., Tirado-Valencia, P., \& De Los Ríos-Berjillos, A. (2018). Can the cultural environment affect governmental transparency on sustainability? Useful measures for policy makers and practitioners. Local Government Studies, 45(4), 481503. https://doi.org/10.1080/03003930.2018.1560271

15. Schedler, K., Proeller, I., \& Jones, L. R. (2007). Cultural Aspects of Public Management Reform. Zaltbommel, Netherlands: Van Haren Publishing.

16. Schröter, E. (2007). Deconstructing Administrative Culture: Exploring the Relationship Between Cultural Patterns and Public Sector Change in the UK and Germany. Schedler, K. and Proeller, I. (Ed.) Cultural Aspects of Public Management Reform. Research in Public Policy Analysis and Management, (16), 299-322. https://doi.org/10.1016/S07321317(07)16012-7

17. Seimas of the Republic of Lithuania. (1999). Law on Public Administration of the Republic of Lithuania (1999 June No. VIII-1234). [accessed 2019-12-11]. Retrieved from https://www.e-tar.lt/portal/lt/legalAct/TAR.0BDFFD850A66/asr

18. Seimas of the Republic of Lithuania. (2018). Law on the State Language of the Republic of Lithuania (2018 June 29 No. XIII-1370). [accessed 2019-09-09]. Retrieved from https://eseimas.lrs.lt/portal/legalAct/lt/TAD/cad5a783834211e89188e16a6495e98c/asr

19. Sharma, R. D. (2002). Conceptual Foundations of Administrative Culture--an Attempt at Analysis of some Variables. International Review of Sociology, 12(1), 65-75. https://doi.org/10.1080/03906700220135336

20. Citizens referendum. (1992). The Constitution of the Republic of Lithuania. (Accepted by the citizens of the Republic of Lithuania in 1992 October 25. Lietuvos aidas 1992, No. 220-0). [accessed 2019-12-11]. Retrieved from https://eseimas.lrs.lt/portal/legalAct /lt/TAD/TAIS.1890/asr

Ramunė Miežanskienė \& Aušra Tartilaitè-Paulauskienė

\section{Tarptautinių studentų patirtys priimančios valstybès viešojo administravimo institucijų veikloje: administracinès kultūros bruožai}

\section{Anotacija}

Straipsnyje aptariamos tarptautinių studentų patirtys, susijusios su Lietuvos viešojo administravimo institucijų veikla, išskiriami iššūkiai su kuriais yra susiduriama, jų mastas ir pobūdis. Atliktas tyrimas atskleidžia, kad didelè dalis tarptautinių studentų, siekdami pasinaudoti administracinèmis procedūromis, susiduria su sunkumais. Pastarieji pasireiškia kaip biurokratija, aiškios bei tikslios informacijos trūkumas. Tyrimo duomenys taip pat atskleidžia respondentų patiriamą viešojo administravimo institucijų tarnautojų nenorą išsamiai pateikti informaciją ar gebejjimų trūkumą tai padaryti. Šioje situacijoje ne mažiau svarbia tampa ir institucijose dominuojanti valstybinès kalbos vartojimo politika, kuri sukelia kliūčių tarptautiniams studentams gauti reikiamą informaciją bei optimaliai naudotis viešosiomis paslaugomis. Minèti veiksniai prisideda prie administracinès kultūros formavimo ypatumų, kurie pasireiškia ir yra išskirtinai juntami būtent imigrantų (užsieniečių) studentų subjektų grupės. Analizuojamu atveju administracinèje kultūroje pasireiškia nepakankamas dėmesys imigrantų poreikiams, o viešojo administravimo institucijų elgsena galètų būti keičiama jų vadovų iniciatyvomis. 
Ramunè Miežanskienè - doktorantè, Kauno technologijos universiteto Socialinių, humanitarinių mokslų ir menų fakulteto lektorè, Lietuva.

email: ramune.miezanskiene@ktu.lt

Aušra Tartilaité-Paulauskiené - Socialinių mokslų daktarè, Kauno technologijos universiteto Socialinių, humanitarinių mokslų ir menų fakulteto docent, Lietuva.

email: ausra.tartilaite@ktu.lt

Ramunè Miežanskiené - Lector, $\mathrm{PhD}$ at the Faculty of Social Sciences Arts and Humanities, Kaunas University of Technology, Lithuania.

email: ramune.miezanskiene@ktu.lt

Aušra Tartilaité-Paulauskienè - Associate Professor at the Faculty of Social Sciences Arts and Humanities, Kaunas University of Technology, Lithuania.

email: ausra.tartilaite@ktu.lt 